\title{
Advances in the management of diabetic macular oedema based on evidence from the Diabetic Retinopathy Clinical Research Network
}

\author{
Lik Thai $\underline{\text { Lim }}^{1}$, FRCophth, Seen Nee $\underline{\text { Chia }}^{1}$, MBChB, Elliott Yann $\underline{\text { Ah-kee }}{ }^{2}$, MBChB, Nejia $\underline{\text { Chew }}{ }^{3}$, MBChB, Manish $\underline{G u p t a}^{1}$, FRCS
}

\begin{abstract}
The Diabetic Retinopathy Clinical Research Network (DRCR.net) performs studies on new treatments for diabetic retinopathy. This review aims to summarise recent findings from DRCR.net studies on the treatment of diabetic macular oedema. We performed a PubMed search of articles from the DRCR.net, which included all studies pertaining to the treatment of diabetic maculopathy. The main outcome measures were retinal thickening as assessed by central subfield thickness on optical coherence tomography and improvement of visual acuity on the Early Treatment Diabetic Retinopathy Study (ETDRS) chart. Findings from each study were divided into modalities of treatment, namely photocoagulation, bevacizumab, triamcinolone, ranibizumab and vitrectomy. While modified ETDRS focal/grid laser remains the standard of care, intravitreal corticosteroids or anti-vascular endothelial growth factor agents have also proven to be effective, although they come with associated side effects. The choice of treatment modality for diabetic macular oedema is a clinical judgement call, and depends on the patient's clinical history and assessment.
\end{abstract}

Keywords: diabetic macular oedema, DRCR.net review, treatment

\section{INTRODUCTION}

The Diabetic Retinopathy Clinical Research Network (DRCR.net) performs multicentre clinical research studies on diabetic retinopathy. It is funded by the National Eye Institute and consists of almost 200 clinical sites distributed throughout the United States. The network, which represents a powerful resource to rapidly assess new treatments, has completed a number of studies that have dramatically enhanced the management of diabetic retinopathy. Secondary manuscripts from assorted DRCR.net studies have also provided useful information on both patient care and study design. A complete list of publications is available from the DRCR.net website.

Diabetic retinopathy is a major cause of blindness in the working-age group (i.e. 25-65 years). Clinically significant diabetic macular oedema (DMO) is the commonest cause of moderate visual loss. Wild et al estimated the worldwide prevalence of diabetes mellitus to be $2.8 \%$. ${ }^{(1)}$ The Wisconsin Epidemiologic Study of Diabetic Retinopathy (WESDR), a population-based study in southern Wisconsin, estimated that the prevalence of DMO after 20 years of known diabetes mellitus was about $28 \%$ in both type 1 and type 2 diabetes mellitus. ${ }^{(2)}$ The incidence over a ten-year period was reported to be $20.1 \%$ in the younger-onset group (before age 30 years), $25.4 \%$ in the olderonset group taking insulin and $13.9 \%$ in the older-onset group not taking insulin. ${ }^{(3)}$ The 25 -year cumulative incidence in type 1 diabetes mellitus was found to be $29 \%$ and $17 \%$ for macular oedema and clinically significant macular oedema, respectively. ${ }^{(4)}$

DMO is defined by the Early Treatment Diabetic Retinopathy Study (ETDRS) as the presence of: (a) retinal thickening at or within
$500 \mu \mathrm{m}$ of the centre of the macula; or b) hard exudates that are associated with adjacent retinal thickening at or within $500 \mu \mathrm{m}$ of the centre of the macula; or (c) zone(s) of retinal thickening of one-disc area or larger, any part of which is within the one-disc diameter of the centre of the macula. ${ }^{(5)}$ Traditionally, DMO is further classified as focal or diffuse based on the leakage pattern on fundus fluorescein angiography (FFA). The DRCR. net studied this classification using time domain optical coherence tomography (OCT) (Stratus OCT-3; Carl Zeiss, Jena, Germany). Browning et al's classification of DMO into focal or diffuse did not explain the variations in visual acuity (VA) or responses to treatment, and there are also inconsistencies in clinical examination, colour fundus photography, FFA and OCT, which were further complicated by hybrid definitions. ${ }^{(6)}$ The hybrid definitions have been used to define diffuse $\mathrm{DMO}$, but not focal DMO. These definitions can be categorised into subgroups based on: (a) clinical examination and FFA criteria; and (b) clinical examination, FFA and OCT criteria.

Extending the concept of focal and diffuse by assessing the number of thickened subfields on OCT showed only modest correlation with baseline acuity but no correlation with subsequent changes in acuity, although OCT has a greater likelihood of detecting cystoid abnormalities compared to FFA. ${ }^{(7,8)}$ OCT and fundus photograph both provide complementary information and have moderate correlation in assessing retinal thickening in DMO. However, this cannot be a surrogate for $\mathrm{VA},{ }^{(9)}$ as there is a wide range of acuity for a given degree of retinal oedema even following laser treatment. ${ }^{(9,10)}$

This review aims to summarise recent findings from DRCR.net studies on the treatment of DMO. The primary outcomes are

${ }^{1}$ Tennent Institute of Ophthalmology, Gartnavel General Hospital, Glasgow, ${ }^{2}$ Monklands Hospital, Airdrie, North Lanarkshire, Scotland, ${ }^{3}$ Eye Department, Royal Victoria Infirmary, Newcastle upon Tyne, Tyne and Wear, England, United Kingdom

Correspondence: Dr Elliott Yann Ah-kee, Monklands Hospital, Monkscourt Avenue, Airdrie, North Lanarkshire, ML6 0JS, United Kingdom. elliottahkee@gmail.com 
reduction in thickening assessed by central subfield thickness (CST) on Stratus OCT-3 and improvement of VA on the ETDRS chart.

\section{METHODOLOGY}

We searched articles from the DRCR.net indexed on PubMed and included all studies pertaining to treatment of diabetic maculopathy. The results were divided into the modality of treatment used in each study. These modalities of treatment were photocoagulation (including focal or grid photocoagulation and scatter photocoagulation), bevacizumab, triamcinolone, ranibizumab and vitrectomy. The outcomes of all the studies according to treatment modality for DMO are summarised in Table I.

\section{PHOTOCOAGULATION Focal/grid photocoagulation}

Focal or grid photocoagulation has been the standard of care in the management of DMO for the past 25 years (as defined by ETDRS). All DRCR.net trials involving laser utilised modified ETDRS (mETDRS) focal/grid photocoagulation, which is the technique widely adopted in current clinical practice. The original ETDRS technique used 50-200 micron spot size argon green or blue-green wavelength, and the "above threshold but less intense than PRP (panretinal photocoagulation) burns" as endpoints. ${ }^{(5)}$ Such intense treatment can result in retinal pigment epithelium atrophy from laser scar expansion, secondary choroidal neovascular membranes and subretinal fibrosis. The gentler mETDRS approach limits the spot size to 50 micron, utilises yellow or green wavelengths, and applies less intense burns (light grey) for the endpoint. ${ }^{(11)}$ Also, grid treatment is applied to areas of thickened retina (and areas of retinal non-perfusion), and direct focal treatment is applied to leaking microaneurysms, but blanching is not required as long as light grey colour change is produced in the subadjacent retinal pigment epithelium.

In a 2007 randomised trial, Fong et al ${ }^{(11)}$ evaluated a different approach using mild macular grid (MMG). This technique differs from mETDRS in that the burns are lighter and more diffused and distributed throughout the macula in both the areas of thickened and unthickened retina; the microaneurysms are also not directly photocoagulated. Subjects had baseline ETDRS VA letter score $\geq 19$ ( $\geq 20 / 400)$. At one year, both MMG and mETDRS led to a reduction in retinal thickening, but mETDRS showed a significantly greater reduction in retinal thickening and greater resolution of DMO $(p=0.01)$. Despite this, VA outcomes between the two approaches were similar. Mean change in VA was 0 letters in $\mathrm{mETDRS}$ and -2 letters in MMG, with improvement of $\geq 15$ letters in $7 \%$ and $5 \%$, respectively, and deterioration of $\geq 15$ letters in $7 \%$ and $10 \%$, respectively. Re-treatment rates of the two approaches at four monthly intervals were also similar, with $33 \%$ of mETDRS and $41 \%$ of MMG re-treated once, and $25 \%$ and $27 \%$, respectively, re-treated twice. In a nutshell, the MMG approach showed no benefit over mETDRS; thus, the authors recommended that $\mathrm{mETDRS}$ focal photocoagulation remain the standard approach for treating DMO. ${ }^{(11)}$
In terms of predicting the VA outcomes following mETDRS laser treatment, an analysis by Aiello et $\mathrm{al}^{(12)}$ in 2010 found greater improvement in eyes that had worse baseline acuity and, conversely, further worsening in eyes that had better baseline acuity or greater retinal thickness. ${ }^{(12)}$ Other factors such as systemic control, OCT morphology, retinopathy severity and prior photocoagulation were not associated with VA outcome. Furthermore, while eyes that initially worsened were more likely to subsequently improve, eyes with acuity $\geq 20 / 32$ were subsequently more likely to worsen due to the ceiling on achieving additional substantial improvement. This ceiling refers to the amount of improvement that can be achieved when VA is only slightly reduced. In eyes with non-centre-involved clinically significant DMO, mETDRS treatment is recommended, as it was found to be effective in stabilising VA and retinal thickness, as well as in decreasing FFA leakage area. At one year, $75 \%$ of patients retained $V A \geq 20 / 25$ from a baseline of 20/40-1 or better. ${ }^{(13)}$

The response to laser is gradual and improvement is usually observed after four months. ${ }^{(12)}$ An observational study of a single mETDRS photocoagulation session involving subjects with ETDRS VA letter score $\geq 24$ ( $\geq 20 / 320)$ demonstrated that four months after the treatment, $28 \%$ had definite reduction but not resolution of oedema, of which $23 \%-63 \%$ would continue to improve without additional treatment over the next four months. ${ }^{(14)}$ Eyes with greater thickening ( $\geq 400$ microns) had a higher frequency of continued improvement. Additional laser treatment was deferred if the VA letter score improved by $\geq 5$ letters, or if OCT CST decreased by $\geq 10 \%$ compared with the findings four months prior. The study concluded that meeting VA deferral criterion alone at four months is poorly predictive of the possibility of subsequent deferral of re-treatment through 48 weeks of follow-up, as $69 \%$ required re-treatment after the four-month visit.

\section{Scatter photocoagulation}

The development of DMO following PRP was compared with PRP given in one or four sittings. ${ }^{(15)}$ Subjects had early proliferative diabetic retinopathy (PDR) or severe non-proliferative diabetic retinopathy (NPDR), baseline OCT-3 CST < 300 microns, and ETDRS VA letter score $\geq 73$ ( $\geq 20 / 32$ ). PRP was delivered with a total of 1200-1600 burns in either one sitting or four sittings at four weekly intervals, with 300 burns applied in each of the first two sittings. Both retinal thickness and VA in both groups worsened initially; the changes were greater when more burns were applied in a single sitting. However, they improved over time such that at subsequent visits, more improvement was observed in the one-sitting group compared with the foursitting group because of the shorter time interval from the last laser sitting. Overall, there was no difference in DMO with PRP delivered in one or four sittings, and both groups were equally controlled in terms of their proliferative disease. However, PRP given in multiple sittings seems more favourable, as it minimises discomfort and reduces the risk of adverse effects such as cystoid macular oedema. 


\section{BEVACIZUMAB}

Bevacizumab is a humanised monoclonal antibody that competitively inhibits all vascular endothelial growth factor (VEGF)-A isoforms within the extracellular space. Currently approved by the Food and Drug Administration (FDA) for the treatment of metastatic breast cancer, metastatic colorectal cancer and non-small cell lung cancer, bevacizumab is also used as an off-label treatment for neovascular age-related macular degeneration, retinal vein occlusion and DMO. The short-term outcomes of intravitreal bevacizumab alone or in combination with mETDRS photocoagulation versus photocoagulation alone were evaluated in a phase II trial. ${ }^{(16)}$ Subjects who had baseline ETDRS VA letter scores of 24-78 (20/320 to 20/32) were followed up for three months. It was found that, compared with photocoagulation, bevacizumab resulted in a greater reduction in central retinal thickness at three weeks, but only gradual improvement was observed with photocoagulation alone, such that no difference was seen after three weeks. Half of the eyes treated with bevacizumab responded with more than $11 \%$ reduction in retinal thickness, although this initial reduction at three weeks decreased after three to six weeks. However, there was a constant one-line improvement in VA with bevacizumab compared to photocoagulation. The study also showed no difference in outcomes between bevacizumab doses of $1.25 \mathrm{mg}$ and $2.5 \mathrm{mg}$. Combined treatment with bevacizumab and photocoagulation did not show any additional short-term benefit.

\section{TRIAMCINOLONE}

A Cochrane review suggests that intravitreal steroids play a role in persistent or refractory DMO. ${ }^{(17)}$ The DRCR.net studies used a preservative-free form of triamcinolone, and results have been discouraging due to unsustainable short-term efficacy and long-term side effects, particularly dose-related intraocular pressure (IOP) elevation and cataract. A randomised trial by the DRCR.net in $2008^{(18)}$ evaluated the effect of two doses of intravitreal triamcinolone acetonide ( $1 \mathrm{mg}$ and $4 \mathrm{mg}$ ) as compared to $\mathrm{mETDRS}$ photocoagulation. Participants had baseline ETDRS VA letter scores of 24-73 (20/320 to 20/40). ${ }^{(19)}$ It was found that, compared with photocoagulation, triamcinolone is less effective and has greater adverse effects at two years, with the results consistent even at three years. ${ }^{(19)}$ Eyes treated with triamcinolone $4 \mathrm{mg}$ showed significant initial VA improvement and reduction in retinal thickness at four months, but these levelled out at one year. By the second and third year, VA in the triamcinolone group was inferior to the group that received photocoagulation, even after taking into account lens changes. Retinal thickness paralleled the acuity changes, with less reduction than laser but no difference between the two triamcinolone doses.

Major adverse events are two times greater with the use of triamcinolone $4 \mathrm{mg}$ compared to triamcinolone $1 \mathrm{mg}$. IOP elevation occurred in $40 \%-50 \%$ of eyes treated with triamcinolone $4 \mathrm{mg}$ compared with $20 \%$ in eyes treated with triamcinolone $1 \mathrm{mg}$, with $13 \%$ and $6 \%$, respectively, requiring IOP-lowering medications by two years. Four eyes in the triamcinolone $4 \mathrm{mg}$ group required glaucoma procedures (two eyes had filtering procedure, one had laser trabeculoplasty and one had ciliary body destruction). Cataract surgery was performed in $51 \%-59 \%$ of eyes treated with triamcinolone $4 \mathrm{mg}$ over two years compared with $23 \%$ in eyes treated with triamcinolone $1 \mathrm{mg} .{ }^{(18)}$ The three-year cumulative probability of development of cataract increased to $83 \%$ in eyes treated with triamcinolone $4 \mathrm{mg}$. Hence, although triamcinolone seemed more effective than laser alone in pseudophakic eyes, there is frequently an increased risk of IOP elevation. The rate of endophthalmitis associated with intravitreal triamcinolone injections was reported to be as low as $0 \%-0.05 \%$; this was achieved with the use of a protocol that included topical povidone-iodine, a sterile lid speculum, topical anaesthetic and post-injection topical antibiotics four times a day for three days (without antibiotic prophylaxis). ${ }^{(20,21)}$

Another trial conducted by Elman et al ${ }^{(22)}$ in 2011 reported findings from a two-year follow-up of a previously reported randomised trial evaluating intravitreal ranibizumab $0.5 \mathrm{mg}$ or triamcinolone $4 \mathrm{mg}$ combined with focal/grid laser, compared with focal/grid laser alone for the treatment of DMO. Elman et al showed that a combination treatment of triamcinolone $4 \mathrm{mg}$ and prompt laser resulted in similar reduction in retinal thickening in the first year but not the second year, with comparable VA improvement with ranibizumab. ${ }^{(22)}$ Among a small number of eyes with the most severe VA loss at baseline (20/200 to 20/320) secondary to DMO, most eyes treated with triamcinolone $4 \mathrm{mg}$ had improvement at two years, but the number was too small (13 eyes) for any meaningful assessment.

Triamcinolone $4 \mathrm{mg}$ also offers additional benefits such as reducing the risks of retinopathy progression and development of vitreous haemorrhage, and lowering the need for PRP over a period of three years. ${ }^{(18)}$ This effect can be sustained without additional injections. ${ }^{(23)}$ The incidence of vitreous haemorrhage is lower in spite of any possibility of cataract obscuring the identification of PDR. However, the use of triamcinolone $4 \mathrm{mg}$ to reduce the likelihood of progression of retinopathy is not warranted due to the increased risks of glaucoma and cataract. ${ }^{(19)}$ In eyes with severe PDR or NPDR, DMO and a ETDRS VA letter score $\geq 24$ ( $\geq 20 / 320)$, PRP and concurrent focal/grid laser for DMO with additional single intravitreal injections of triamcinolone $4 \mathrm{mg}$ resulted in better VA and decreased macular oedema for 4-14 weeks. ${ }^{(24)}$ The efficacy and side effect profile is similar if two intravitreal injections of ranibizumab $0.5 \mathrm{mg}$ were given instead. Even in the short term, the risks are reduced for the development of vitreous haemorrhage, tractional retinal detachment, need for vitrectomy, or requirement of additional focal/grid laser treatment for DMO. Elevation of IOP is more frequent in triamcinolone (17\%). ${ }^{(24)}$ Hence the long-term risks need to be weighed against the short-term benefits.

Limited efficacy and an unfavourable side effect profile were also observed with subtenon injection of triamcinolone. In a phase II study, ${ }^{(25)}$ anterior and posterior subtenon injection of triamcinolone, either alone or in combination with focal photocoagulation was evaluated in mild DMO. In this study, anterior injection of triamcinolone $20 \mathrm{mg}$ was given beneath the bulbar conjunctiva under the lower lid and posterior injection of triamcinolone $40 \mathrm{mg}$ 
was given in the subtenon's space of the superior temporal quadrant, about $10 \mathrm{~mm}$ posterior to the limbus. Participants had baseline ETDRS VA letter scores $\geq 69$ ( $\geq 20 / 40$ ), a mean acuity letter score of 79 (20/25) and mean OCT CST of 328 microns. No substantial benefit of using peribulbar triamcinolone with or without focal photocoagulation in DMO was reported, with good VA noted compared with photocoagulation alone. There was reduction in retinal thickening in all treated eyes and worsening of mean acuity letter score of 1-4. The results of anterior and posterior subtenon injections were similar. Combined peribulbar triamcinolone and focal photocoagulation resulted in a $50 \%$ reduction in the need for re-treatment, as compared with laser treatment alone. However, the authors warned that the investigators were not blinded to the treatment groups. Furthermore, based on the investigators' judgement, any true benefit of peribulbar triamcinolone for mild $\mathrm{DMO}$ is unlikely to exceed a mean improvement of 13 microns in retinal thickness on the grounds of the re-treatment criteria of $\geq 250$ microns retinal thickness or macular oedema. ${ }^{(25)}$

In terms of the two-year safety profile, anterior peribulbar injection was associated with an increased incidence of IOP elevation and more substantial cataract formation, presumably due to higher steroid levels in the anterior segment with this delivery modality. ${ }^{(26)}$ IOP elevation is 4.2 times more likely to occur with anterior peribulbar injection compared to laser, and 2.3 times more likely to occur compared to posterior injection. The rates of IOP elevations with anterior peribulbar triamcinolone were similar to those previously reported for intravitreal triamcinolone, with a third having IOP elevation $\geq 10 \mathrm{mmHg}$ and requiring IOP-lowering medications, although none had required glaucoma surgery. Cataract progression or extraction were significantly higher in anterior injection (62\%) compared with posterior injection (38\%) and laser (27\%). Posterior injection carries a higher risk of ptosis compared with anterior injection $(12 \%$ vs. $6 \%)$; there is, however, no risk of ptosis in laser alone. As adverse effects may not be seen until the second year of treatment, long-term follow-up is advised in eyes treated with peribulbar corticosteroid.

\section{RANIBIZUMAB}

Like bevacizumab, ranibizumab is also a VEGF inhibitor administered intravitreally. It was licensed in the European Union for the treatment of DMO in March 2011 following the outcomes of company-sponsored RESOLVE and RESTORE studies. In the phase II RESOLVE study, ranibizumab at doses $\leq 1.0 \mathrm{mg}$ (three monthly injections and subsequently as needed) was found to be more effective than sham injections in improving functional and anatomical outcomes in patients with DMO. ${ }^{(27)}$ In the phase III RESTORE study, ranibizumab $0.5 \mathrm{mg}$ (three monthly injections and subsequently as needed), either alone or combined with laser therapy, was shown to be more effective than laser alone in improving functional and anatomical outcomes in patients with DMO. ${ }^{(28)}$

A phase III DRCR.net study ${ }^{(29)}$ evaluated the outcome of intravitreal ranibizumab $0.5 \mathrm{mg}$ or triamcinolone $4 \mathrm{mg}$ combined with focal/grid laser compared with focal/grid laser alone for treatment of DMO. Subjects in this study had ETDRS VA letter scores of 24-78 (20/320 to 20/32). Ranibizumab with prompt/ deferred (after 24 weeks) laser resulted in superior VA and central retinal thickness at one and two years, as compared with prompt laser alone. Significantly more eyes gained substantial vision ( $50 \%$ of eyes had improvement of $\geq 10$ letter scores from the baseline) and significantly fewer eyes lost substantial vision $(4 \%)(p=0.01)$. Improvement in eyes treated with ranibizumab mostly occurred by two months and continued to improve through one year, stabilising thereafter. Ranibizumab also reduced the progression of diabetic retinopathy, the development of vitreous haemorrhage or the need for PRP, with the effects sustained for up to two years. The median number of ranibizumab injections was eight in one year. Treatment with combined ranibizumab and deferred laser did not obviate the need for focal/grid laser; onethird of eyes required at least one laser treatment. ${ }^{(29)}$ The results of a three-year follow-up study of the same randomised controlled trial suggest that focal/grid laser treatment at the initiation of intravitreal ranibizumab was no better, and possibly worse for vision outcomes, than deferring laser treatment for $\geq 24$ weeks in eyes with $\mathrm{DMO}$ involving the fovea and those with vision impairment. Ongoing follow-up of this protocol will continue over a five-year period. ${ }^{(30)}$

An analysis of VA outcomes and OCT thickness following intravitreal ranibizumab did not identify any factors associated with poor outcomes at one year following treatment, due to the low number of participants with vision loss or increase in CST. ${ }^{(31)}$ However, this study identified possible predictors of better visual outcomes, including CST evolution, younger age, less severe diabetic retinopathy on clinical examination and absence of surface wrinkling retinopathy. ${ }^{(31)}$ This can be useful when balancing the risks and benefits of ranibizumab for centre-involved DMO.

Ranibizumab injections are uncommonly associated with infectious endophthalmitis $(0.8 \%)$ and a theoretical risk of traction retinal detachment in PDR $(0.3 \%)$. There is a $9 \%$ increased risk of IOP elevation for ranibizumab and a cumulative percentage of $14 \%$ that undergo cataract surgery over two years, but both incidences are much lower compared with that for triamcinolone $4 \mathrm{mg}$. Furthermore, ranibizumab has a longer-term outcome of five years, which reinforces that ranibizumab should be considered in DMO. ${ }^{(18)}$

Another DRCR.net study assessed the use of ranibizumab in eyes with severe NPDR or PDR and DMO with ETDRS VA letter score $\geq 24$ (> 20/320). ${ }^{(32)}$ In eyes that received PRP and concurrent focal/grid laser for DMO, two additional injections of intravitreal ranibizumab $0.5 \mathrm{mg}$ enhanced VA improvement and decreased macular oedema by 14 weeks. VA improvement usually occurred within one month, with no difference noted between PRP performed in single or multiple sittings. In addition, ranibizumab-treated eyes were less likely to develop vitreous haemorrhage and tractional retinal detachment, or require vitrectomy or additional focal/grid laser treatment for DMO. The side effect profile is similar in the short and long term.

As with triamcinolone injections, the rate of endophthalmitis is reportedly low, i.e. $0.09 \%$ per injection or $0.65 \%$ per eye, and 
the overall incidence ranged from $0.4 \%$ to $0.8 \%$ with intravitreal ranibizumab. ${ }^{(29,32,33)}$ Cultures isolated were mainly coagulase negative Staphylococcus with one case of Streptococcus viridans reported. There was no difference in systemic adverse events such as cardiovascular or cerebrovascular events compared with sham injections or triamcinolone in all studies. ${ }^{(29,32,33)}$ This information may be useful when discussing the risks and benefits of different treatment modalities with patients who have cardiovascular comorbidities.

\section{VITRECTOMY}

In one study, vitrectomy for the treatment of DMO and vitreomacular traction was shown to reduce CTO in most eyes, with $28 \%-49 \%$ experiencing improvement of VA and $13 \%-31 \%$ worsening. ${ }^{(34)}$ The surgical complication rate for vitrectomy was low. The baseline ETDRS VA letter score was 19-63 (20/63 to 20/400) and Stratus OCT retinal CST was $>300$ microns. PDR (in two-thirds) and vitreomacular traction were indications for vitrectomy. Standard pars plana vitrectomy was performed via three pars plana sclerotomies, removal of vitreous gel, with peeling of the posterior hyaloid if attached and removal of the peripheral vitreous, leaving only a small residual vitreous skirt; engagement and peeling of the epiretinal membrane (ERM) judged visually significant; and treatment of any peripheral breaks with laser or cryotherapy. Cataract extraction was not performed in conjunction with vitrectomy and $40 \%$ received PRP intraoperatively. ${ }^{(34)}$

Following vitrectomy, VA gains observed at six months are more likely to continue improving, whereas VA loss at six months is less likely to improve. Removal of ERM may favourably affect visual outcome after vitrectomy, reflecting resolution of distorted vision from the ERM rather than resolution of DMO. ${ }^{(12)}$ Central retinal thickness decreased by $\geq 50 \%$ at six months in two-thirds of individuals with baseline OCT central retinal thickness $\geq 250$ microns, and half of these eyes had retinal thickness $<250$ microns at one year. Eyes with greater CST at baseline tended to have greater reduction in thickness after surgery. Preoperative vitreoretinal abnormalities are associated with somewhat greater reductions in retinal thickness but not with VA outcome. Except for cases with very large decreases in CST of $>350$ microns, a given decrease in thickness on OCT was associated with a wide range of changes in VA. Postoperative complications occurred in $18 \%$ in the first six months, including vitreous haemorrhage, retinal detachment and endophthalmitis. Most phakic eyes (78\%) developed lens changes by six months and half of the studied eyes underwent cataract surgery within one year. Additional DMO treatment with intravitreal corticosteroid, anti-VEGF and macular laser were each given in $26 \%$ of the eyes. However, no significant changes in VA or CST were noted between six months and one year following these procedures. ${ }^{(34)}$

\section{CONCLUSION}

The DRCR.net is an effective network for research that has facilitated the rapid assessment of new treatments for diabetic retinopathy, DMO and associated conditions without any drug company funding. The trend in the management of DMO continues to evolve. While mETDRS focal/grid laser remains the standard of care due to its safety profile, its gradual effects are supervened by intravitreal corticosteroids or anti-VEGF, which also offer the additional benefit of reducing diabetic retinopathy progression. In the short term, intravitreal ranibizumab and triamcinolone result in greater $\mathrm{VA}$ and retinal thickening outcomes. However, these two agents require maintenance with repeated injections and also have longer-term associated side effects and higher costs. Triamcinolone in particular has unfavourable effects such as elevation of IOP and cataract development. Ranibizumab carries a theoretical increased risk of tractional retinal detachment. Vitrectomy with ERM peel improves anatomical structure but has variable VA outcomes. In light of new evidence on the management of DMO, the most suitable modality of treatment would depend on the clinical history and assessment of each case in its own right. The clinician will have to use good clinical judgement in the planning of each case of DMO.

\section{REFERENCES}

1. Wild S, Roglic G, Green A, Sicree R, King H. Global prevalence of diabetes: estimates for the year 2000 and projections for 2030. Diabetes Care 2004; 27:1047-53.

2. Klein R, Klein BE, Moss SE, Davis MD, DeMets DL. The Wisconsin epidemiologic study of diabetic retinopathy. IV. Diabetic macular edema. Ophthalmology 1984; 91:1464-74.

3. Klein R, Klein BE, Moss SE, Cruickshanks KJ. The Wisconsin Epidemiologic Study of Diabetic Retinopathy. XV. The long-term incidence of macular edema. Ophthalmology 1995; 102:7-16.

4. Klein R, Knudtson MD, Lee KE, Gangnon R, Klein BE. The Wisconsin Epidemiologic Study of Diabetic Retinopathy XXIII: the twenty-fiveyear incidence of macular edema in persons with type 1 diabetes. Ophthalmology 2009; 116:497-503.

5. Photocoagulation for diabetic macular edema. Early Treatment Diabetic Retinopathy Study report number 1. Early Treatment Diabetic Retinopathy Study research group. Arch Opthalmol 1985; 103:1796-806.

6. Browning DJ, Altaweel MM, Bressler NM, Bressler SB, Scott IU; Diabetic Retinopaty Clinical Research Network. Diabetic macular edema: what is focal and what is diffuse? Am J Ophthalmol 2008; 146:649-55.

7. Browning DJ, Apte RS, Bressler SB, et al; Diabetic Retinopathy Clinical Research Network. Association of the extent of diabetic macular edema as assessed by optical coherence tomography with visual acuity and retinal outcome variables. Retina 2009; 29:300-5.

8. Danis RP, Scott IU, Qin H, et al; Diabetic Retinopathy Clinical Research Network. Association of fluorescein angiographic features with visual acuity and with optical coherence tomographic and stereoscopic color fundus photographic features of diabetic macular edema in a randomized clinical trial. Retina 2010; 30:1627-37.

9. Davis MD, Bressler SB, Aiello LP, et al; Diabetic Retinopathy Clinical Research Network Study Group. Comparison of time-domain OCT and fundus photographic assessments of retinal thickening in eyes with diabetic macular edema. Invest Ophthalmol Vis Sci 2008; 49:1745-52.

10. Diabetic Retinopathy Clinical Research Network, Browning DJ, Glassman AR, et al. Relationship between optical coherence tomographymeasured central retinal thickness and visual acuity in diabetic macular edema. Ophthalmology 2007; 114:525-36.

11. Writing Committee for the Diabetic Retinopathy Clinical Research Network, Fong DS, Strauber SF, et al. Comparison of the modified Early Treatment Diabetic Retinopathy Study and mild macular grid laser photocoagulation strategies for diabetic macular edema. Arch Ophthalmol 2007; 125:469-80.

12. Aiello LP, Edwards AR, Beck RW, et al; Diabetic Retinopathy Clinical Research Network. Factors associated with improvement and worsening of visual acuity 2 years after focal/grid photocoagulation for diabetic macular edema. Ophthalmology 2010; 117:946-53.

13. Scott IU, Danis RP, Bressler SB, et al; Diabetic Retinopathy Clinical Research Network. Effect of focal/grid photocoagulation on visual acuity 
and retinal thickening in eyes with non-center-involved diabetic macular edema. Retina 2009; 29:613-7.

14. Diabetic Retinopathy Clinical Research Network. The course of response to focal/grid photocoagulation for diabetic macular edema. Retina 2009 29:1436-43.

15. Diabetic Retinopathy Clinical Research Network, Brucker AJ, Qin H, et al. Observational study of the development of diabetic macular edema following panretinal (scatter) photocoagulation given in 1 or 4 sittings. Arch Ophthalmol 2009; 127:132-40.

16. Diabetic Retinopathy Clinical Research Network, Scott IU, Edwards AR, et al. A phase II randomized clinical trial of intravitreal bevacizumab for diabetic macular edema. Ophthalmology 2007; 114:1860-7.

17. Grover D, Li TJ, Chong CC. Intravitreal steroids for macular edema in diabetes. Cochrane Database Syst Rev 2008; CD005656.

18. Diabetic Retinopathy Clinical Research Network. A randomized trial comparing intravitreal triamcinolone acetonide and focal/grid photocoagulation for diabetic macular edema. Ophthalmology 2008; 115:1447-9, 1449.e1-10.

19. Diabetic Retinopathy Clinical Research Network (DRCR.net), Beck RW, Edwards AR, et al. Three-year follow-up of a randomized trial comparing focal/grid photocoagulation and intravitreal triamcinolone diabetic macular edema. Arch Ophthalmol 2009; 127:245-51.

20. Bhavsar AR, Googe JM Jr, Stockdale CR, et al; Diabetic Retinopathy Clinical Research Network. Risk of endophthalmitis after intravitral drug injection when topical antibiotics are not required: the diabetic retinopathy clinica research netweork laser-ranibizumab-triamcinolone clinical trials. Arch Ophthalmol 2009; 127:1581-3.

21. Bhavsar AR, Ip MS, Glassman AR; DRCRnet and the SCORE Study Groups. The risk of endophthalmitis following intravitreal triamcinolone injection in the DRCRnet and SCORE clinical trials. Am J Opthalmol 2007; 144:454-6.

22. Elman MJ, Bressler NM, Qin H, et al; Diabetic Retinopathy Clinical Research Network. Expanded 2-year follow-up of ranibizumab plus prompt or deferred laser or triamcinolone plus prompt laser for diabetic macular edema. Ophthalmology 2011; 118:609-14.

23. Bressler NM, Edwards AR, Beck RW, et al; Diabetic Retinopathy Clinical Research Network. Exploratory analysis of diabetic retinopathy progression through 3 years in a randomized clinical trial that compares intravitreal triamcinolone acetonide with focal/grid photocoagulation. Arch Ophthalmol 2009; 127:1566-71.

24. Diabetic Retinopathy Clinical Research Network, Googe J, Brucker AJ, et al. Randomized trial evaluating short-term effects of intravitral ranibizumab or triamcinolone acetonide on macular edema after focal/grid laser for diabetic macular edema in eyes also receiving panretinal photocoagulation. Retina 2011; 31:1009-27.

25. Diabetic Retinopathy Clinical Research Network, Chew E, Strauber S, et al Randomized trial of peribulbar triamcinolone acetonide with and without focal photocoagulation for mild diabetic macular edema: a pilot study. Ophthalmology 2007; 144:1990-6.

26. Chew EY, Glassman AR, Beck RW, et al; Diabetic Retinopathy Clinical Research Network. Ocular side effects associated with peribulbar injections of triamcinolone acetonide for diabetic macular edema. Retina 2011; 31:284-9.

27. Massin P, Bandello F, Garweg JG, et al. Safety and efficacy of ranibizumab in diabetic macular edema (RESOLVE Study): a 12-month, randomized, controlled, double-masked, multicentre phase II study. Diabetes Care 2010; 33:2399-405.

28. Mitchell P, Bandello F, Schmidt-Erfurth U, et al; RESTORE study group. The RESTORE study: ranibizumab monotherapy or combined with laser versus laser monotherapy for diabetic macular edema. Ophthalmology $2011 ; 118: 615-25$

29. Diabetic Retinopathy Clinical Research Network, Elman MJ, Aiello LP, et al. Randomized trial evaluating ranibizumab plus prompt or deferred laser or triamcinolone plus prompt laser for diabetic macular edema. Ophthalmology 2010; 117:1064-1077.

30. Diabetic Retinopathy Clinical Research Network, Elman MJ, Qin H, et al. Intravitreal ranibizumab for diabetic macular edema with prompt versus deferred laser treatment: three-year randomized trial results. Ophthalmology 2012; 119:2312-8.

31. Bressler SB, Qin H, Beck RW, et al; Diabetic Retinopathy Clinical Research Network. Factors associated with changes in visual acuity and central subfield thickness at 1 year after treatment for diabetic macular edema with ranibizumab. Arch Ophthalmol 2012; 130:1153-61.

32. Diabetic Retinopathy Clinical Research Network, Googe J, Brucker AJ, et al. Randomized trial evaluating short-term effects of intravitreal ranibizumab or triamcinolone acetonide on macular edema after focal/grid laser for diabetic macular edema in eyes also receiving panretinal photocoagulation. Retina 2011; 31:1009-27.

33. Bhavsar AR, Googe JM Jr, Stockdale CR, et al; Diabetic Retinopathy Clinical Research Network. Risk of endophthalmitis after intravitreal drug injection when topical antibiotics are not required: the diabetic retinopathy clinical research network laser-ranibizumab-triamcinolone clinical trials. Arch Ophthalmol 2009; 127:1581-3.

34. Diabetic Retinopathy Clinical Research Network Writing Committee, Haller JA, Qin $\mathrm{H}$, et al. Vitrectomy outcomes in eyes with diabetic macular edema and vitreomacular traction. Ophthalmology 2010; 117:1087-1093.e3. 
Table I. Summary of outcomes according to treatment modalities for diabetic macular oedema (DMO).

\begin{tabular}{|c|c|c|c|c|c|c|}
\hline $\begin{array}{l}\text { Treatment } \\
\text { modality }\end{array}$ & Study design & Participants & Re-treatment & Outcome & Adverse effects & Authors' comments \\
\hline \multicolumn{7}{|c|}{$\begin{array}{l}\text { Focal/Grid } \\
\text { photocoagulation }\end{array}$} \\
\hline mETDRS & $\begin{array}{l}\text { RCT; } 12 \text { mth; } \\
142 \text { subjects }{ }^{(11)}\end{array}$ & $\begin{array}{l}\text { DMO with VA } \geq 19 \\
(\geq 20 / 400) \text {; OCT retinal } \\
\text { thickening } \geq 250 \mu \mathrm{m} \text { in } \\
\text { CST or } \geq 300 \mu \mathrm{m} \text { in at } \\
\text { least one of the four } \\
\text { inner subfields; no prior } \\
\text { laser or DMO treatment }\end{array}$ & $\begin{array}{l}\text { None: } 42 \% \text {; once: } 33 \% \text {; } \\
\text { twice: } 25 \%\end{array}$ & $\begin{array}{l}\text { Mean decrease of CST: } 88 \mu \mathrm{m}^{*} \text {; all subfields } \\
\text { within normal range: } 23 \% \text {; mean decrease in } \\
\text { DMO area on fundus photo: } 0.2 D^{*} \text {; mean } \\
\text { change in VA: } 0 \text { letters; gain } \geq 15 \text { letters: } 7 \% \text {; } \\
\text { loss } \geq 15 \text { letters: } 7 \%\end{array}$ & None & $\begin{array}{l}\text { mETDRS remains the } \\
\text { standard of care }\end{array}$ \\
\hline mETDRS & $\begin{array}{l}\text { Phase II RCT; } \\
12 \text { wk; } 19 \text { eyes in } \\
\text { laser alone group }{ }^{(16)}\end{array}$ & $\begin{array}{l}\text { DMO with VA } 78-24 \\
\text { letters }(20 / 32-20 / 320) \text {; } \\
\text { OCT CST } \geq 275 \mu \mathrm{m} \text {; one } \\
\text { eye per subject }\end{array}$ & $79 \%$ & $\begin{array}{l}3 w k \text { median change in CST: }+21 \mu \mathrm{m} ; 3 \mathrm{wk} \\
<250 \mu \mathrm{m} \text { or } \geq 50 \% \text { CST reduction: } 11 \% ; \\
12 \text { wk median change in CST: }-40 \mu \mathrm{m} ; 12 \mathrm{wk} \\
<250 \mu \mathrm{m} \text { or } \geq 50 \% \text { CST reduction: } 21 \% ; 3 \text { wk } \\
\text { median change in VA: }-2 \text { letters; } \\
12 \text { wk median change in VA: }-1 \text { letter; } \\
\text { gain } \geq 15 \text { letters: } 5 \% \text {; loss } \geq 10 \text { letters: } 5 \%\end{array}$ & $\begin{array}{l}\text { Anaemia (1); peripheral vascular } \\
\text { disease (2); hypertension (1); } \\
\text { worsening renal function (1) }\end{array}$ & $\begin{array}{l}\text { After } 3 \text { wk, no } \\
\text { difference in retinal } \\
\text { thickening but less one } \\
\text { line VA compared to } \\
\text { bevacizumab }\end{array}$ \\
\hline mETDRS & $\begin{array}{l}\text { Observational; } \\
12 \text { mth; } \\
24 \text { subjects }{ }^{(13)}\end{array}$ & $\begin{array}{l}\text { Non-centre-involved } \\
\text { DMO: CST }<250 \mu \mathrm{m} \\
\text { and photography } \\
\text { assessment of retinal } \\
\text { thickness at the centre } \\
\text { of the macula graded as } \\
\text { 'none' or 'questionable' }\end{array}$ & - & $\begin{array}{l}\text { Median decrease of retinal thickness: } \\
4-12 \mu \mathrm{m} \text {; CST decreased } \geq 25 \mu \mathrm{m}: 18 \% \text {; } \\
\text { mean decrease in DMO area on fundus } \\
\text { photo: } 0.2 \mathrm{DD} \text {; fluorescein leakage: }-0.7 \mathrm{DA} ; \\
\text { decrease } \geq 1 \text { DA fluorescein leakage: } 44 \% \text {; } \\
\text { DMO area in fundus photo: }+0.21 \text { DA; median } \\
\text { change in VA: }-1 \text { letter; gain } \geq 5 \text { letters: } 18 \% \text {; } \\
\text { loss } \geq 5 \text { letters: } 32 \%\end{array}$ & None & $\begin{array}{l}\text { mETDRS appropriate } \\
\text { in non-centre-involved } \\
\text { DMO }\end{array}$ \\
\hline mETDRS & $\begin{array}{l}\text { Observational; } \\
24 \text { mth; } 115 \text { eyes }^{(14)}\end{array}$ & $\begin{array}{l}\text { DMO with VA } \geq 24 \\
\text { letters }(\geq 20 / 320) \text {; } \\
\text { CST } \geq 250 \mu \mathrm{m}\end{array}$ & $21 \%$ & $\begin{array}{l}\text { Decrease CST } \geq 10 \% \text { at } 16 \text { wk: } 47 \% \text {; } \\
\text { gain } \geq 5 \text { letters: } 35 \%, \text { loss } \geq 5 \text { letters: } 19 \% ; \\
\text { further decrease } \mathrm{CST} \geq 10 \% \text { after } 16 \text { wk: } 10 \% \text {; } \\
\text { gain } \geq 5 \text { letters: } 35 \%, \text { loss } \geq 5 \text { letters: } 19 \%\end{array}$ & None & $\begin{array}{l}\text { In eyes with definite } \\
\text { reduction but not } \\
\text { resolution of central } \\
\text { oedema at } 16 \text { wk; } \\
23 \%-63 \% \text { continue } \\
\text { to improve without } \\
\text { further treatment }\end{array}$ \\
\hline mETDRS & $\begin{array}{l}\text { Phase III RCT; } \\
2 \text { yr \& } 3 \text { yr; } \\
330 \text { eyes in laser } \\
\text { alone }^{(12)}\end{array}$ & $\begin{array}{l}\text { DMO with VA } 73-24 \\
\text { letters }(20 / 40-20 / 320) \\
\text { OCT thickness } \\
\geq 250 \mu \mathrm{m}\end{array}$ & $\begin{array}{l}\text { Mean no. of treatment: } \\
2 \mathrm{yr}(2.9) ; 3 \mathrm{yr}(3.1)\end{array}$ & $\begin{array}{l}\text { Median change in CST: } 2 \mathrm{yr}(-131 \mu \mathrm{m}) \text {, } \\
3 \mathrm{yr}(-158 \mu \mathrm{m}) ; \text { median change in VA letters: } \\
4 \mathrm{mth}(+2), 2 \mathrm{yr}(+4), 3 \mathrm{yr}(+8) ; \text { gain } \geq 15 \\
\text { letters: } 2 \mathrm{yr}(18 \%), 3 \mathrm{yr}(26 \%) ; \text { loss } \geq 15 \\
\text { letters: } 2 \mathrm{yr}(14 \%), 3 \mathrm{yr}(8 \%)\end{array}$ & $\begin{array}{l}\text { Retinal detachment (2), retinal } \\
\text { vein occlusion (3), retinal artery } \\
\text { occlusion (1), vitrectomy ( } 31) \text {, } \\
\text { IOP elevation }(10 \%) \text {, cataract } \\
\text { surgery }(13 \%)\end{array}$ & $\begin{array}{l}\text { Focal/grid laser is } \\
\text { more effective and } \\
\text { has fewer side effects } \\
\text { than } 1 \mathrm{mg} \text { or } 4 \mathrm{mg} \\
\text { triamcinolone }\end{array}$ \\
\hline
\end{tabular}




\begin{tabular}{|c|c|c|c|c|c|c|}
\hline $\begin{array}{l}\text { Treatment } \\
\text { modality }\end{array}$ & Study design & Participants & Re-treatment & Outcome & Adverse effects & Authors' comments \\
\hline mETDRS & $\begin{array}{l}\text { Phase } 3 \text { RCT; } \\
1 \text { yr \& } 2 \text { yr; } \\
293 \text { eyes in sham } \\
\text { injection + prompt } \\
\text { laser }^{(22)}\end{array}$ & $\begin{array}{l}\text { DMO with VA } 78-24 \\
\text { letters }(20 / 32-20 / 320) \text {, } \\
\text { OCT CST } \geq 250 \mu \mathrm{m}\end{array}$ & $\begin{array}{l}\text { Median no. of } \\
\text { treatment: } 1 \text { yr (3); } \\
\text { laser by } 48 \text { wk: } 26 \%\end{array}$ & $\begin{array}{l}\text { Median change in CST: } 1 \mathrm{yr}(-79 \mu \mathrm{m}), \\
2 \mathrm{yr}(-104 \mu \mathrm{m}) ; \text { CST }<250 \mu \mathrm{m} \text { and } \geq 25 \mu \mathrm{m} \\
\text { reduction: } 1 \mathrm{yr}(27 \%), 2 \mathrm{yr}(38 \%) ; \text { median } \\
\text { change in VA letters: } 1 \mathrm{yr}(+5), 2 \mathrm{yr}(+6) ; \text { gain } \\
\geq 15 \text { letters: } 1 \mathrm{yr}(15 \%), 2 \mathrm{yr}(18 \%) ; \text { loss } \geq 15 \\
\text { letters: } 1 \mathrm{yr}(8 \%), 2 \mathrm{yr}(10 \%) ; \text { DR progression } \\
\text { at } 1 \mathrm{yr} \text { : improved }(22 \%), \text { worsened }(15 \%)\end{array}$ & $\begin{array}{l}2 \text { yr: retinal detachment }(0) \text {; } \\
\text { vitrectomy }(5 \%) \text {; vitreous } \\
\text { haemorrhage }(9 \%) \text {; elevation of } \\
\text { IOP/glaucoma }(11 \%) \text {; glaucoma } \\
\text { surgery }(<1 \%) \text {; cataract surgery } \\
(12 \%)\end{array}$ & $\begin{array}{l}\text { Gradual improvement } \\
\text { during the first year } \\
\text { with stabilisation } \\
\text { thereafter }\end{array}$ \\
\hline $\begin{array}{l}\text { Mild macular } \\
\text { grid }\end{array}$ & $\begin{array}{l}\text { RCT; } 12 \text { mth; } \\
162 \text { eyes }^{(11)}\end{array}$ & $\begin{array}{l}\text { DMO with } V A \geq 19 \\
\text { letters }(\geq 20 / 400) \text {; } \\
\text { OCT retinal thickening } \\
\geq 250 \mu \mathrm{m} \text { in central } \\
\text { subfield or } \geq 300 \mu \mathrm{m} \text { in } \\
\text { at least one of the four } \\
\text { inner subfields; no prior } \\
\text { laser or DMO treatment }\end{array}$ & $\begin{array}{l}\text { None: } 33 \% \text {; once: } 41 \% \text {; } \\
\text { twice: } 27 \%\end{array}$ & $\begin{array}{l}\text { Mean decrease of CST: } 49 \mu \mathrm{m} \text {; all subfields } \\
\text { within normal range: } 17 \% \text {; mean decrease in } \\
\text { DMO area on fundus photo: } 0.08 \mathrm{DD} \text {; mean } \\
\text { change in VA: }-2 \text { letters; gain } \geq 15 \text { letters: } \\
5 \% \text {; loss } \geq 15 \text { letters: } 10 \%\end{array}$ & $\begin{array}{l}\text { One neurosensory detachment, } \\
\text { which resolved after } 1 \mathrm{mth}\end{array}$ & $\begin{array}{l}\text { Mild macular grid is } \\
\text { not recommended for } \\
\text { DMO }\end{array}$ \\
\hline \multicolumn{7}{|c|}{$\begin{array}{l}\text { Scatter } \\
\text { photocoagulation }\end{array}$} \\
\hline $\begin{array}{l}\text { PRP in } 1 \& 4 \\
\text { sittings }\end{array}$ & $\begin{array}{l}\text { RCT; } 34 \text { wk; in } 1 \\
\text { sitting: } 84 \text { eyes; } \\
\text { in } 4 \text { sittings: } \\
71 \text { eyes }^{(15)}\end{array}$ & $\begin{array}{l}\text { Early PDR or severe } \\
\text { NPDR, VA } \geq 73 \text { letters } \\
(\geq 20 / 32), \text { OCT } \\
\text { CST }<300 \mu \mathrm{m}\end{array}$ & $\begin{array}{l}\text { In } 1 \text { sitting: } 7 \% \text {; in } 4 \\
\text { sittings: } 0 \%\end{array}$ & $\begin{array}{l}\text { In } 1 \text { sitting: } \\
\text { Median no. of burns: } 1,274 \text {; retrobulbar } \\
\text { anaesthetic injection: } 46 \% * ; 3 \text { day median } \\
\text { change in CST: }+9 \mu \mathrm{m}^{*} ; 4 \text { wk median } \\
\text { change in CST: }+13 \mu \mathrm{m}^{*} ; 17 \text { wk median } \\
\text { change in CST: }+14 \mu \mathrm{m} ; 34 \text { wk median } \\
\text { change in CST: }+14 \mu \mathrm{m} ; 3 \text { day median } \\
\text { change in VA: }-3 \text { letters*; } 34 \text { wk median } \\
\text { change in VA: } 0 \text { letters* } \\
\text { In } 4 \text { sittings: } \\
\text { Median no. of burns: } 1,260 \text {; retrobulbar } \\
\text { anaesthetic injection: } 14 \% \text {; } 3 \text { day median } \\
\text { change in CST: }+5 \mu \mathrm{m} ; 4 \text { wk median } \\
\text { change in CST: }+5 \mu \mathrm{m} ; 17 \text { wk median } \\
\text { change in CST: }+15 \mu \mathrm{m} ; 34 \text { wk median } \\
\text { change in CST: }+22 \mu \mathrm{m} ; 3 \text { day median } \\
\text { change in VA: }-1 \text { letters; } 34 \text { wk median } \\
\text { change in VA: }-2 \text { letters }\end{array}$ & $\begin{array}{l}\text { Significant vitreous haemorrhage: } \\
2 \text { eyes in each group }\end{array}$ & $\begin{array}{l}\text { Scatter PRP can be } \\
\text { safely administered in } \\
\text { a single sitting }\end{array}$ \\
\hline
\end{tabular}




\begin{tabular}{|c|c|c|c|c|c|c|}
\hline $\begin{array}{l}\text { Treatment } \\
\text { modality }\end{array}$ & Study design & Participants & Re-treatment & Outcome & Adverse effects & Authors' comments \\
\hline $\begin{array}{l}\text { PRP in 1-3 } \\
\text { sittings + focal/ } \\
\text { grid + sham } \\
\text { injections }\end{array}$ & $\begin{array}{l}\text { Phase III study; } \\
14 \text { wk; } 123 \text { eyes }^{(24)}\end{array}$ & $\begin{array}{l}\text { DMO with severe } \\
\text { NPDR or PDR; VA } \geq 24 \\
\text { letters }(\geq 20 / 320) ; \text { OCT } \\
\text { CST } \geq 250 \mu \mathrm{m}\end{array}$ & $\begin{array}{l}\text { Additional PRP: } 24 \% \text {; } \\
\text { additional DMO Rx: } 59 \%\end{array}$ & $\begin{array}{l}\text { Median change in CST: } 0 \mu \mathrm{m} ; \text { CST }<250 \mu \mathrm{m} \\
\text { and } \geq 25 \mu \mathrm{m} \text { reduction: } 10 \% \text {; median change } \\
\text { in VA letters: }-2 \text {; gain } \geq 15 \text { letters: } 4 \% \text {; loss } \geq \\
15 \text { letters: } 15 \%\end{array}$ & $\begin{array}{l}56 \text { wk: endophthalmitis }(0) \text {; } \\
\text { retinal detachment (4); } \\
\text { vitrectomy (17); vitreous } \\
\text { haemorrhage (28); IOP elevation } \\
\text { (14); glaucoma surgery (0); } \\
\text { cataract surgery (2) }\end{array}$ & $\begin{array}{l}\text { Eyes with centre- } \\
\text { involved DMO } \\
\text { receiving prompt PRP } \\
\text { at the time of focal/ } \\
\text { grid laser for DMO are } \\
\text { more likely to have } \\
\text { increased macular } \\
\text { oedema and VA loss in } \\
\text { the short-term }\end{array}$ \\
\hline \multicolumn{7}{|l|}{ Bevacizumab } \\
\hline $\begin{array}{l}1.25 \mathrm{mg} \text { at } \\
0+6 \mathrm{wk} \\
2.5 \mathrm{mg} \text { at } \\
0+6 \mathrm{wk} \\
1.25 \mathrm{mg} \text { at } \\
\text { baseline only } \\
\& 1.25 \mathrm{mg} \text { at } \\
0+6 \mathrm{wk} / \text { laser } \\
\text { at } 3 \mathrm{wk}\end{array}$ & $\begin{array}{l}\text { Phase } 2 \text { RCT, } \\
12 \text { wk; in } 1.25 \mathrm{mg} \\
\text { at } 0+6 \text { wk: } \\
22 \text { eyes; in } 2.5 \mathrm{mg} \\
\text { at } 0+6 \text { wk: } \\
24 \text { eyes; in } 1.25 \mathrm{mg} \\
\text { at baseline only: } \\
22 \text { eyes; in } 1.25 \mathrm{mg} \\
\text { at } 0+6 \text { wk/laser } \\
\text { at } 3 \text { wk: } 22 \text { eyes }\end{array}$ & $\begin{array}{l}\text { DMO with VA } 78-24 \\
\text { letters }(20 / 32-20 / 320) \text {, } \\
\text { OCT CST } \geq 275 \mu \mathrm{m} \text {, } \\
\text { one eye per subject }\end{array}$ & $\begin{array}{l}\text { In } 1.25 \mathrm{mg} \text { at } 0+6 \mathrm{wk} \text { : } \\
67 \% \text {; in } 2.5 \mathrm{mg} \\
\text { at } 0+6 \mathrm{wk}: 67 \% \text {; } \\
\text { in } 1.25 \mathrm{mg} \text { at baseline } \\
\text { only: } 86 \% \text {; in } 1.25 \mathrm{mg} \\
\text { at } 0+6 \mathrm{wk} / \text { laser at } \\
3 \mathrm{wk}: 75 \%\end{array}$ & 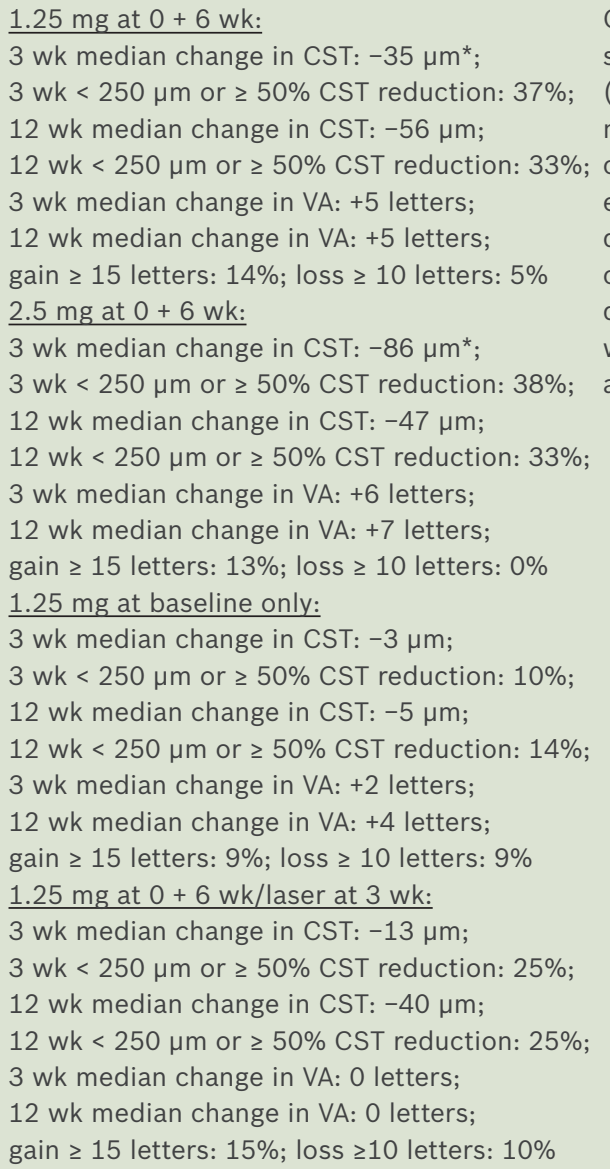 & $\begin{array}{l}\text { Coagulase negative } \\
\text { staphylococcus endophthalmitis } \\
\text { (1); transient raised IOP (1); } \\
\text { myocardial infarction (2); } \\
\text { congestive heart failure (1); } \\
\text { elevation of blood pressure (3); } \\
\text { death due to pancreatic } \\
\text { cancer (1); peripheral vascular } \\
\text { disease (1); syncope (1); } \\
\text { worsening renal function (3); } \\
\text { anaemia (4) }\end{array}$ & $\begin{array}{l}\text { Bevacizumab } 1.25 \mathrm{mg} \\
\text { or } 2.5 \mathrm{mg} \text { result in one } \\
\text { line VA improvement } \\
\text { compared to laser, } \\
\text { but no difference } \\
\text { in CST after } 3 \mathrm{wk} \text {; } \\
\text { bevacizumab } 2.5 \mathrm{mg} \\
\text { unlikely to produce } \\
\text { greater short-term } \\
\text { CST reduction } \\
\text { than } 1.25 \mathrm{mg} \text {; CST } \\
\text { reduction at } 3 \text { wk } \\
\text { plateau or decrease, } \\
\text { hence } 6 \text { wk injection } \\
\text { interval is too long; no } \\
\text { short-term benefit or } \\
\text { adverse outcomes in } \\
\text { combination therapy } \\
\text { with laser }\end{array}$ \\
\hline
\end{tabular}




\begin{tabular}{|c|c|c|c|c|c|c|}
\hline $\begin{array}{l}\text { Treatment } \\
\text { modality }\end{array}$ & Study design & Participants & Re-treatment & Outcome & Adverse effects & Authors' comments \\
\hline \multicolumn{7}{|l|}{ Triamcinolone } \\
\hline 1 mg \& 4 mg & $\begin{array}{l}\text { Phase III RCT; } \\
2 \text { yr \& } 3 \text { yr; } 1 \text {-mg } \\
\text { group: } 256 \text { eyes; } \\
\text { 4-mg group: } \\
254 \text { eyes }^{(23)}\end{array}$ & $\begin{array}{l}\text { DMO with VA } 73-24 \\
\text { letters }(20 / 40-20 / 320) \\
\text { OCT thickness } \\
\geq 250 \mu \mathrm{m}\end{array}$ & $\begin{array}{l}\text { 1-mg group: mean no. } \\
\text { of treatment: } 1 \text { yr (2.3); } \\
2 \mathrm{yr}(3.5) ; 3 \mathrm{yr}(4.2) \\
\text { 4-mg group: mean no. } \\
\text { of treatment: } 1 \text { yr (2.1); } \\
2 \mathrm{yr}(3.1) \text {; } \\
3 \mathrm{yr}(4.1)\end{array}$ & $\begin{array}{l}\text { In 1-mg group: } \\
\text { Median change in CST: } 2 \mathrm{yr}(-74 \mu \mathrm{m}), \\
3 \mathrm{yr}(-103 \mu \mathrm{m}) ; \text { median change in VA } \\
\text { letters: } 4 \mathrm{mth}(+2), 2 \mathrm{yr}(+1), 3 \mathrm{yr}(+2) ; \\
\text { gain } \geq 15 \text { letters: } 2 \mathrm{yr}(14 \%), 3 \mathrm{yr}(20 \%) ; \\
\text { loss } \geq 15 \text { letters: } 2 \mathrm{yr}(20 \%), 3 \mathrm{yr}(17 \%) \\
\text { In 4-mg group: } \\
\text { Median change in CST: } 2 \mathrm{yr}(-76 \mu \mathrm{m}), \\
3 \mathrm{yr}(-114 \mu \mathrm{m}) ; \text { median change in VA letters: } \\
4 \mathrm{mth}(+5), 2 \mathrm{yr}(+2), 3 \mathrm{yr}(+4) ; \text { gain } \geq 15 \\
\text { letters: } 2 \mathrm{yr}(17 \%), 3 \mathrm{yr}(21 \%) ; \text { loss } \geq 15 \\
\text { letters: } 2 \mathrm{yr}(20 \%), 3 \mathrm{yr}(16 \%)\end{array}$ & $\begin{array}{l}\text { 1-mg group: retinal } \\
\text { detachment (2); retinal vein } \\
\text { occlusion (1); anterior } \\
\text { ischaemic optic neuropathy } \\
\text { (1); vitrectomy (26); } \\
\text { IOP elevation }(20 \%) ; \\
\text { cataract surgery }(23 \%) \\
\text { 4-mg group: retinal } \\
\text { detachment (4); retinal vein } \\
\text { occlusion (2); vitrectomy (19); } \\
\text { glaucoma procedures }(4) ; \\
\text { IOP elevation }(40 \%) ; \\
\text { cataract surgery }(51 \%)\end{array}$ & $\begin{array}{l}\text { Focal/grid laser is } \\
\text { more effective and } \\
\text { has fewer side effects } \\
\text { than } 1 \mathrm{mg} \text { or } 4 \mathrm{mg} \\
\text { triamcinolone }\end{array}$ \\
\hline $\begin{array}{l}4 \mathrm{mg}+\text { prompt } \\
\text { laser }\end{array}$ & $\begin{array}{l}\text { Phase III RCT; } \\
1 \text { yr \& } 2 \text { yr; } \\
186 \text { eyes }^{(29)}\end{array}$ & $\begin{array}{l}\text { DMO with VA } 78-24 \\
\text { letters }(20 / 32-20 / 320) \\
\text { OCT CST } \geq 250 \mu \mathrm{m}\end{array}$ & $\begin{array}{l}\text { Median no. of } \\
\text { injections: } 1 \text { yr (3), } \\
2 \text { yr (4); median no. of } \\
\text { laser: } 2 \text { yr (3); laser by } \\
48 \text { wk: } 21 \%\end{array}$ & $\begin{array}{l}\text { Median change in CST: } 1 \mathrm{yr}(-90 \mu \mathrm{m}) \text {, } \\
2 \mathrm{yr}(-96 \mu \mathrm{m}) ; \text { CST < } 250 \mu \mathrm{m} \text { and } \geq 25 \mu \mathrm{m} \text {; } \\
\text { reduction: } 1 \mathrm{yr}(47 \%), 2 \mathrm{yr}(45 \%) ; \text { median } \\
\text { change in VA letters: } 1 \mathrm{yr}(+5), 2 \mathrm{yr}(+6) \text {; gain } \\
\geq 15 \text { letters: } 1 \mathrm{yr}(21 \%), 2 \mathrm{yr}(22 \%) \text {; loss } \geq 15 \\
\text { letters: } 1 \mathrm{yr}(8 \%), 2 \mathrm{yr}(13 \%) ; \text { DR progression } \\
\text { at } 1 \mathrm{yr} \text { improved }(38 \%), \text { worsened }(6 \%)\end{array}$ & $\begin{array}{l}2 \text { yr: pseudoendophthalmitis (1\%); } \\
\text { ocular vascular event }(2 \%) ; \\
\text { vitrectomy }(1 \%) \text {; vitreous } \\
\text { haemorrhage }(4 \%) \text {; elevation of } \\
\text { IOP/glaucoma }(50 \%) \text {; glaucoma } \\
\text { surgery }(1 \%) \text {; cataract surgery } \\
(55 \%)\end{array}$ & $\begin{array}{l}\text { Effective in } \\
\text { pseudophakics but } \\
\text { frequently increases } \\
\text { the risk of IOP } \\
\text { elevation }\end{array}$ \\
\hline $\begin{array}{l}4 \mathrm{mg}+ \\
\text { focal/grid } \\
\text { laser + PRP }\end{array}$ & $\begin{array}{l}\text { Phase III study; } \\
14 \text { wk; } 109 \text { eyes }^{(24)}\end{array}$ & $\begin{array}{l}\text { DMO with severe } \\
\text { NPDR or PDR; VA } \geq 24 \\
\text { letters ( } \geq 20 / 320) \text {; OCT } \\
\text { CST } \geq 250 \mu \mathrm{m} \text {; receiving } \\
\text { PRP }\end{array}$ & $\begin{array}{l}\text { Additional PRP: } 23 \% \text {; } \\
\text { additional DMO Rx: } 42 \% *\end{array}$ & $\begin{array}{l}\text { Median change in CST: }-75 \mu \mathrm{m}^{*} ; \text { CST } \\
<250 \mu \mathrm{m} \text { and } \geq 25 \mu \mathrm{m} \text { reduction: } 27 \% \text {; median } \\
\text { change in VA letters: }+1^{*} ; \text { gain } \geq 15 \text { letters: } \\
10 \% \text {; loss } \geq 15 \text { letters: } 3 \%\end{array}$ & $\begin{array}{l}56 \text { wk: endophthalmitis }(0) ; \\
\text { retinal detachment (1); } \\
\text { vitrectomy ( } 7) \text {; vitreous } \\
\text { haemorrhage (31); IOP elevation } \\
\text { (30); glaucoma surgery (1); } \\
\text { cataract surgery (6) }\end{array}$ & $\begin{array}{l}\text { The addition of } \\
\text { one intravitreal } \\
\text { triamcinolone injection } \\
\text { can reduce short-term } \\
\text { exacerbation of DMO } \\
\text { and associated VA } \\
\text { loss after PRP in eyes } \\
\text { that are also receiving } \\
\text { focal/grid laser }\end{array}$ \\
\hline \multicolumn{7}{|l|}{ Ranibizumab } \\
\hline $\begin{array}{l}0.5 \mathrm{mg}+\text { prompt } \\
\text { laser \& } 0.5 \mathrm{mg}+ \\
\text { deferred laser }\end{array}$ & $\begin{array}{l}\text { Phase III RCT; } \\
1 \text { yr \& } 2 \text { yr; } \\
0.5 \mathrm{mg}+\text { prompt } \\
\text { laser: } 187 \text { eyes; } \\
0.5 \mathrm{mg}+\text { delayed } \\
\text { laser: } 188 \text { eyes }^{(22)}\end{array}$ & $\begin{array}{l}\text { DMO with VA } 78-24 \\
\text { letters }(20 / 32-20 / 320) \\
\text { OCT CST } \geq 250 \mu \mathrm{m}\end{array}$ & $\begin{array}{l}0.5 \mathrm{mg}+\text { prompt laser: } \\
\text { median no. of } \\
\text { injections: } 1 \mathrm{yr}(8) \text {, } \\
2 \mathrm{yr}(11) \text {; median no. of } \\
\text { laser: } 2 \mathrm{yr}(2) \text {; laser by } \\
48 \text { wk: } 16 \% \text {; } 0.5 \mathrm{mg} \\
\text { + deferred laser: } \\
\text { median no. of } \\
\text { injections: } 1 \text { yr (9); }\end{array}$ & $\begin{array}{l}\text { 0.5 mg + prompt laser: } \\
\text { Median change in CST: } 1 \mathrm{yr}(-112 \mu \mathrm{m}), \\
2 \mathrm{yr}(-113 \mu \mathrm{m}) ; \text { CST < } 250 \mu \mathrm{m} \text { and } \geq 25 \mu \mathrm{m} ; \\
\text { reduction: } 1 \mathrm{yr}(53 \%), 2 \mathrm{yr}(54 \%)^{*} ; \text { median } \\
\text { change in VA letters: } 1 \mathrm{yr}(+10)^{*}, 2 \mathrm{yr}(+8) ; \\
\text { gain } \geq 15 \text { letters: } 1 \mathrm{yr}(30 \%), 2 \mathrm{yr}(29 \%)^{*} ; \\
\text { loss } \geq 15 \text { letters: } 1 \mathrm{yr}(2 \%), 2 \mathrm{yr}(4 \%)^{*} ; \\
\text { DR progression at } 1 \mathrm{yr} \text { : improved }(53 \%) \\
\text { worsened }(4 \%)\end{array}$ & $\begin{array}{l}0.5 \mathrm{mg}+\text { prompt laser: } \\
2 \text { yr: endophthalmitis }(1 \%) ; \\
\text { ocular vascular event }(2 \%) ; \\
\text { vitrectomy }(2 \%) ; \\
\text { vitreous haemorrhage }(3 \%) ; \\
\text { elevation of IOP/glaucoma }(11 \%) ; \\
\text { glaucoma surgery }(1 \%) ; \\
\text { cataract surgery }(12 \%)\end{array}$ & $\begin{array}{l}\text { Recommended in DMO } \\
\text { whether with deferred } \\
\text { or prompt laser; } \\
\text { endophthalmitis is } \\
\text { uncommon, but there } \\
\text { is a theoretical risk } \\
\text { of increased traction } \\
\text { retinal detachments } \\
\text { in PDR }\end{array}$ \\
\hline
\end{tabular}




\begin{tabular}{|c|c|c|c|c|c|c|}
\hline $\begin{array}{l}\text { Treatment } \\
\text { modality }\end{array}$ & Study design & Participants & Re-treatment & Outcome & Adverse effects & Authors' comments \\
\hline & & & $\begin{array}{l}2 \text { yr (13); median no. of } \\
\text { laser: } 2 \text { yr (0); } \\
\text { laser by } 48 \text { wk: } 8 \%\end{array}$ & $\begin{array}{l}\text { In } 0.5 \mathrm{mg}+\text { deferred laser: } \\
\text { Median change in CST: } 1 \mathrm{yr}(-111 \mu \mathrm{m}) \\
2 \mathrm{yr}(-129 \mu \mathrm{m}) ; \text { CST < } 250 \mu \mathrm{m} \text { and } \geq 25 \mu \mathrm{m} ; \\
\text { reduction: } 1 \mathrm{yr}(42 \%), 2 \mathrm{yr}(56 \%)^{*} ; \text { median } \\
\text { change in VA letters: } 1 \mathrm{yr}(+9)^{*}, 2 \mathrm{yr}(+9) ; \\
\text { gain } \geq 15 \text { letters: } 1 \mathrm{yr}(28 \%), 2 \mathrm{yr}(28 \%)^{*} ; \\
\text { loss } \geq 15 \text { letters: } 1 \mathrm{yr}(2 \%), 2 \mathrm{yr}(2 \%)^{*} ; \\
\text { DR progression at } 1 \mathrm{yr} \text { : improved }(53 \%) \\
\text { worsened }(4 \%)\end{array}$ & $\begin{array}{l}0.5 \mathrm{mg}+\text { deferred laser: } \\
2 \text { yr: endophthalmitis }(1 \%) ; \\
\text { ocular vascular event }(2 \%) ; \\
\text { retinal detachment }(1 \%) ; \\
\text { vitrectomy }(4 \%) \text {, vitreous } \\
\text { haemorrhage }(4 \%) \text {; elevation of } \\
\text { IOP/glaucoma ( }(7 \%) \text {; glaucoma } \\
\text { surgery (0); cataract surgery } \\
(13 \%)\end{array}$ & \\
\hline $\begin{array}{l}0.5 \mathrm{mg} \text { at } \\
0+4 \mathrm{wk}+ \\
\text { focal/grid } \\
\text { laser + PRP }\end{array}$ & $\begin{array}{l}\text { Phase III study; } \\
14 \text { wk; } 113 \text { eyes }^{(24)}\end{array}$ & $\begin{array}{l}\text { DMO with severe } \\
\text { NPDR or PDR, VA } \geq 24 \\
\text { letters }(\geq 20 / 320) \\
\text { OCT CST } \geq 250 \mu \mathrm{m} \text {, } \\
\text { receiving PRP }\end{array}$ & $\begin{array}{l}\text { Additional PRP: } 19 \% \text {; } \\
\text { additional DMO Rx: } 44 \% *\end{array}$ & $\begin{array}{l}\text { Median change in CST: }-26 \mu \mathrm{m}^{*} ; \text { CST } \\
<250 \mu \mathrm{m} \text { and } \geq 25 \mu \mathrm{m} \text { reduction: } 17 \% \text {; median } \\
\text { change in VA letters: }+2^{*} \text {; gain } \geq 15 \text { letters: } 7 \% \text {; } \\
\text { loss } \geq 15 \text { letters: } 7 \%\end{array}$ & $\begin{array}{l}56 \text { wk: endophthalmitis (1); } \\
\text { retinal detachment (6); } \\
\text { vitrectomy (8); vitreous } \\
\text { haemorrhage ( } 31 \text { ); IOP } \\
\text { elevation (12); glaucoma } \\
\text { surgery (1); cataract surgery (3) }\end{array}$ & $\begin{array}{l}\text { The addition of } \\
\text { two intravitreal } \\
\text { ranibizumab injections } \\
\text { can reduce short-term } \\
\text { exacerbation of DMO } \\
\text { and associated VA loss } \\
\text { after PRP, in eyes also } \\
\text { receiving focal/grid } \\
\text { laser }\end{array}$ \\
\hline \multicolumn{7}{|l|}{ Vitrectomy } \\
\hline $\begin{array}{l}\text { Standard } \\
\text { pars plana } \\
\text { vitrectomy } \\
\text { without } \\
\text { concomitant } \\
\text { cataract } \\
\text { extraction }\end{array}$ & $\begin{array}{l}\text { Observational; } \\
6 \text { mth; } 87 \text { eyes }^{(34)}\end{array}$ & $\begin{array}{l}\text { Vitreomacular traction } \\
\text { as indication; VA 19-63 } \\
\text { letters (20/400-20.63), } \\
\text { OCT CST > } 300 \mu \mathrm{m}\end{array}$ & $\begin{array}{l}\text { Additional PRP (0); } \\
\text { macular laser (4); } \\
\text { intravitreal } \\
\text { corticosteroid (2); } \\
\text { anti-VEGF (2) }\end{array}$ & $\begin{array}{l}\text { Median change in CST: } 3 \mathrm{mth} \& 6 \mathrm{mth} \\
(-160 \mu \mathrm{m})^{*} \text {; CST < } 250 \mu \mathrm{m}: 43 \% \text {; median VA: } \\
3 \mathrm{mth}(20 / 100), 6 \mathrm{mth}(20 / 100) ; \text { gain } \geq 15 \\
\text { letters: } 3 \mathrm{mth}(22 \%), 6 \mathrm{mth}(38 \%) \text {; loss } \geq 15 \\
\text { letters: } 3 \mathrm{mth}(23 \%), 6 \mathrm{mth}(22 \%)\end{array}$ & $\begin{array}{l}\text { Vitreous haemorrhage }(6 \%) \text {; } \\
\text { retinal detachment }(3 \%) \text {; } \\
\text { endophthalmitis ( } 1 \%) \text {; IOP } \\
\text { elevation ( } 8 \%) \text {; cataract } \\
\text { surgery within } 1 \text { yr }(46 \%)\end{array}$ & $\begin{array}{l}\text { Following vitrectomy } \\
\text { for DMO and } \\
\text { vitreomacular } \\
\text { traction, macular } \\
\text { thickening is reduced } \\
\text { with variable VA } \\
\text { outcome ( } 28 \%-49 \% \\
\text { improving and } \\
13 \%-31 \% \text { worsening); } \\
\text { epiretinal membrane } \\
\text { removal has better VA } \\
\text { outcome; preoperative } \\
\text { vitreoretinal } \\
\text { abnormalities result in } \\
\text { greater CST reductions } \\
\text { but not VA outcomes }\end{array}$ \\
\hline
\end{tabular}

*Significant at $p<0.05$ when compared with standard of care. CST was measured using OCT. CST: central subfield thickness; IOP: intraocular pressure; mETDRS: modified Early Treatment Diabetic Retinopathy Study; NPDR: nonproliferative diabetic retinopathy; OCT: optical coherence tomography; PDR: proliferative diabetic retinopathy; PRP: panretinal photocoagulation; RCT: randomised control trial; VA: visual acuity; VEGF: vascular endothelial growth factor 